\title{
The Twin Defect-Radio-diagnostic Notes from a Classic Case of Localized Aggressive Periodontitis
} \author{
Gowri P Bhandarkar ${ }^{2}$ \\ ${ }^{1}$ Postgraduate Student, Department of Oral Medicine and Radiology, AJ Institute of Dental Sciences, India \\ ${ }^{2}$ Reader, Department of Oral Medicine and Radiology, AJ Institute of Dental Sciences, India \\ ${ }^{3}$ Professor and Head, Department of Oral Medicine and Radiology, AJ Institute of Dental Sciences, India \\ ${ }^{4}$ Professor, Department of Oral Medicine and Radiology, AJ Institute of Dental Sciences, India \\ ${ }^{5}$ Assistant Professor, Department of Oral Medicine and Radiology, AJ Institute of Dental Sciences, India
}

Brilliant Raphael ${ }^{1}$, Geon Pauly ${ }^{1}$, Roopashri Rajesh Kashyap ${ }^{2}$, Raghavendra Kini ${ }^{3}$, Prasanna Kumar Rao ${ }^{4}$ and

Submission: January 01, 2017; Published: January 31, 2018

*Corresponding author: Geon Pauly N, Postgraduate student, Department of Oral Medicine and Radiology, A J Institute of Dental Sciences, Kuntikana, NH-66 Mangaluru, PIN-575004, Karnataka, India, Tel: +918905102696; Email: geonpauly@gmail.com

\section{Abstract}

An inflammatory condition of the supporting tissues of the teeth is termed periodontitis. Periodontal diseases, in general, ranges from benign gingivitis to chronic and aggressive forms of the disease. Its onset is caused by the presence of biofilm and metabolic products of microorganisms involved. Periodontitis is currently recognized in two principal forms: Chronic and aggressive periodontitis. Aggressive periodontitis is much severe form of periodontitis. Our case highlights one of the classic radiographic features of the localized form of this condition.

\section{Case Report}

A 45-year-old male patient reported to our department with a chief complaint of pain and a mild swelling in the right side of the face since 2 weeks. The patient gave a history of a dull aching pain, intermittent in nature since 2 weeks and an associated swelling and a progressive restriction in mouth opening since 1 week. A thorough intra-oral examination was not possible as the mouth opening was extremely limited. Since an IOPA was not possible ailing to the above mentioned reason, a panoramic radiograph was advised. The radiograph revealed an arc shaped bone loss extending from distal to first molar to mesial of third molar region and a floating second molar, both features seen as a mirror image bilaterally (Figure 1). A final diagnosis of localized aggressive periodontitis was established and patient was advised for extraction of the mandibular second molars followed by periodontal and prosthetic evaluation.

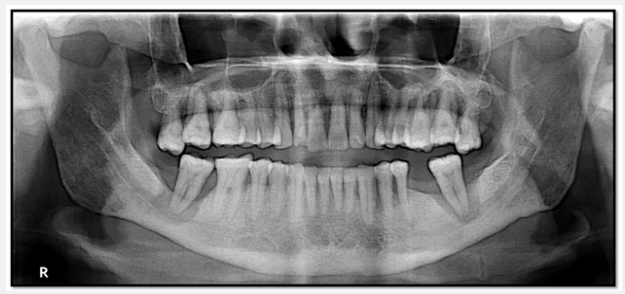

Figure 1: Localized periodontitis in mandibular second molar region bilaterally exhibiting a mirror image arc-shaped bone loss and floating teeth.

\section{Discussion}

Aggressive periodontitis is a rare, destructive disease which is often accompanied by severe and rapid loss of periodontal attachment [1]. Aggressive periodontitis, formerly known as juvenile periodontitis, generally affects systemically healthy individuals in the first decades of life, and is characterized by a young age of onset, rapid rate of disease progression, and familial aggregation of cases [2]. Older individuals can also be

affected, but are comparatively rare to find which puts our case amidst the fewer lot. It is characterized by rapid vertical loss of the supporting alveolar bone, resulting in infra-bony pouches more than four millimetres deep.

These infra-bony pouches can lead to compromise of the furcation and cause mobility in permanent teeth [3]. Aggressive periodontitis can be classified as localized and generalized. The localized form is characterized as to affect first molars and permanent incisors, with loss of supporting alveolar bone and the generalized in no more than two teeth other than first molars and incisors which is not as in our case [4]. Radiographic findings may include an 'arc-shaped' loss of alveolar bone extending from the distal surface of the second premolar to the mesial surface of the second molar. Bone defects are usually wider than usually seen with chronic periodontitis. 
Frequently, bilaterally symmetrical patterns of bone loss results forming a 'mirror image pattern' as witnessed in our case [5]. Early detection is critically important in the treatment of aggressive periodontitis for preventing further destruction is often more advocated than attempting to regenerate lost supporting tissues. One of the most important aspects of treatment success is to educate the patient about the disease, including the causes and the risk factors for disease, and to stress the importance of the patient's role in the success of treatment [6].

\section{Conclusion}

Aggressive periodontitis is a rare but severe form of periodontitis and it is essentially important to distinguish it from the other types so that timely intervention and the appropriate treatment can be devised and undertaken.

This work is licensed under Creative Commons Attribution 4.0 Licens DOI: 10.19080/OAJS.2018.07.555720

\section{References}

1. Singh S, Shreehari AK (2016) Aggressive Periodontitits: A Diagnostic Dilemma. Dentistry 4(5): 1-8.

2. Srinivas SR (2014) Low Levels of Caries in Aggressive Periodontitis: A Literature Review. The Saudi Dental Journal 26: 47-49.

3. Monteiro Me F, Casati MZ, Taiete T, Vale HF, Nociti FH, et al. (2015) Periodontal Clinical and Microbiological Characteristics in Healthy Versus Generalized Aggressive Periodontitis Families. J Clin Periodontol 42(10): 914-921.

4. Toniazzo MP, Lopes Daudt FAR (2017) Family Aggregation as a Diagnostic Factor for Aggressive Periodontitis. JSM Clinical Case Reports 5(4): 1138.

5. Singh B, Garg A, Garg RK (2013) Aggressive Periodontitis: A Review. Dental Journal of Advance Sciences 1(3): 129-135.

6. Newman MG, Takei HH, Klokkevold PR, Carranza FA (2011) Carranza's Clinical Period ontology. (11 $1^{\text {th }}$ edn), St. Louis: Saunders, Australia.

\section{Your next submission with Juniper Publishers} will reach you the below assets

- Quality Editorial service

- Swift Peer Review

- Reprints availability

- E-prints Service

- Manuscript Podcast for convenient understanding

- Global attainment for your research

- Manuscript accessibility in different formats

( Pdf, E-pub, Full Text, Audio)

- Unceasing customer service

Track the below URL for one-step submission https://juniperpublishers.com/online-submission.php 